ISSN 0258-7122 (Print), 2408-8293 (Online)

Bangladesh J. Agril. Res. 41(4): 735-757, December 2016

\title{
SOIL FERTILITY STATUS OF SOME OF THE INTENSIVE CROP GROWING AREAS UNDER MAJOR AGRO-ECOLOGICAL ZONES OF BANGLADESH
}

\author{
N. C. SHIL ${ }^{1}$, M. A. SALEQUE ${ }^{2}$, M. R. ISLAM ${ }^{3}$ AND M. JAHIRUDDIN ${ }^{3}$
}

\begin{abstract}
Laboratory studies on soil fertility evaluation was carried out across major agroecological zones (AEZs) of Bangladesh to know the nutrient status of soils and to relate those with soil properties like $\mathrm{pH}$, organic matter, CEC, and clay content. Thirty five composite soil samples were collected from intensive crop growing sites, which covered 17 AEZs of Bangladesh. After proper processing, the samples were analyzed for texture, $\mathrm{pH}$, organic carbon, $\mathrm{CEC}$, exchangeable cations $(\mathrm{K}, \mathrm{Ca}, \mathrm{Mg}$ and $\mathrm{Na}$ ), total $\mathrm{N}$, available $\mathrm{P}$ and $\mathrm{S}$ following standard methods. The textural class of the soils collected from AEZ 12 and 13 appeared to be mostly clay. Clay loam soil was found in AEZ 4, 8, 9, 11, 25 and 28. Loamy soil was seen in AEZ 1 while AEZ 22, 23 and 29 were mostly sandy textured. The results revealed that $65.7 \%$ of the tested soil was acidic while $25.7 \%$ was alkaline in nature. All the tested soils showed lower $\mathrm{pH}_{\mathrm{KCl}}$ compared to $\mathrm{pH}_{\mathrm{H} 2 \mathrm{O}}$ thus possessed negative charge. About $68.6 \%$ of the collected soils contained low (1.10-1.70\%) level of organic matter, $25.7 \%$ soils retained it at medium level $(1.71-2.40)$ and $5.7 \%$ soils at very low level $(<1.0 \%)$. All the tested soils appeared to be deficient $(<0.12 \%)$ in nitrogen content. $68.6 \%$ soil samples had the low level of available $\mathrm{P}$ while only $8.6 \%$ retained it an optimum amount. About $80 \%$ of the tested soils contained low level of available S (7.9$14.7 \mathrm{mg} \mathrm{kg}^{-1}$ ) although coastal regions soils hold higher amount of available $\mathrm{S}$. High CEC (20-38 $\left.\mathrm{cmol} \mathrm{kg}^{-1}\right)$ was found in clay rich soils of AEZ 10, 11, 12, and 13. Study revealed that $40 \%$ of the collected soils were very low, $31.4 \%$ were low, $8.6 \%$ each of medium and optimum, and $11.4 \%$ contained high level of exchangeable K. The calcareous soils (AEZ 10, 11, 12 and 13) contained very high level of $\mathrm{Ca}$. Non calcareous soils also showed fairly good level of $\mathrm{Ca}$ content except AEZ 1, 3, 23 and 29. Sandy textured soils of greater Dinajpur, Rangpur, Moulvibazar showed lower level of exchangeable Mg. About $86 \%$ of the tested soils had the lower $(<2 \%)$ potassium saturation percentage (KSP), which needs $\mathrm{K}$ application for sustainable crop production. Estimate showed that $44 \%$ variability for CEC may be attributed by clay content and the relationship was significant $(\mathrm{p}=0.05)$. Again, 50.4 and $65.6 \%$ variability in exchangeable $\mathrm{K}$ and $\mathrm{Mg}$, respectively may be governed by clay content of the soils, while such relationship for $\mathrm{Ca}$ was non-significant. CEC may contribute 62.2, 92.3 and $83.9 \%$ variability for exchangeable $\mathrm{K}, \mathrm{Ca}$ and $\mathrm{Mg}$ content in soils, respectively. The fertility status of most of the studied soils (except AEZ
\end{abstract}

${ }^{1}$ Principal Scientific Officer, Soil Science Division, Bangladesh Agricultural Research Institute (BARI), Gazipur, ${ }^{2}$ Coordinator for Advanced Studies and Research, Bangladesh Rice Research Institute (BRRI), Gazipur, ${ }^{3}$ Professor, Soil Science Department, Bangladesh Agricultural University (BAU), Mymensingh, Bangladesh. 
$10,12,13$ and to some extent 11) appeared to be low to very low, which demand judicious management in order to achieve food security and to conserve the soil fertility.

Keywords: Soil fertility, agro-ecological zones, texture, organic matter, cation exchange capacity

\section{Introduction}

Even though Bangladesh is a small country, but it has wide variation and complexity of soils due to diverse nature of physiography, parent materials, land type, drainage conditions and agro ecology. Depending on these aspects, the country has been divided into 30 agro ecological zones (AEZ), which varied greatly in respect of area, land and soil, climate, and cropping intensity (FAOUNDP, 1988). Some AEZs are very potential for crop agriculture and nutrient supplying capacity but some are being depleted due to intensive cropping.

Increasing cropping to meet the demands for food for a swelling population has led to mining out the inherent plant nutrients from the crop fields thereby fertility status of the soils severely declined in Bangladesh over the years (Ali et al., 1997 and Khan et al., 2008). The use of chemical fertilizers as the supplemental source has been increasing steadily but these are not applied in balanced proportion. Of the total fertilizer used in the country, urea alone constituted about 75\% (FRG, 2012). Previous study indicated that about $60 \%$ cultivable land of Bangladesh is deficient in N, P and K (Miah et al., 2008). Moreover, organic matter content in country's soils is low, the majority being below the thresh hold level $(1.5 \%)$ and it was gradually depleted by 5 to 36\% during the period of 1967-1995 (Ali et al., 1997). Islam (2008) mentioned that organic matter content in Bangladesh soils is generally around $1 \%$ in most and around $2 \%$ in few soils. Sulfur deficiency in Bangladesh soils is supposed to be increased gradually due to increased use of high analysis $\mathrm{S}$ free fertilizers over the years, higher removal by HYV crops, prolonged submergence for rice cultivation and low level of organic matter. Soils are being disturbed vigorously through tillage operation like plowing, puddling, laddering and so on, leading to higher rate of decomposition of organic matter.

The fertility status of Bangladesh soils is not available widely. The systematic work in this regard is very scarce. The information in this regard available so far is mostly old one. Soil fertility is a dynamic phenomenon and the magnitude of change depends on how intensively the land is used, nutrients are added and removed by the crops. It is, therefore, felt necessary for the evaluation of the fertility status of Bangladesh soils to update and make information available to the scientists, extension personnel, students as well as policy makers for the judicious management of soil resources for achieving food security ensuring better soil health for sustainability. Keeping this view in mind, the present studies were undertaken across major agro-ecological zones (AEZs) of Bangladesh in 
order to know the nutrient status of soils and to relate those with soil properties like $\mathrm{pH}$, organic matter, $\mathrm{CEC}$, exchangeable bases and clay content.

\section{Materials and Method}

Sites: Soil collection sites were selected mostly on the basis of the cropping intensity of the region covering major agro ecological zones (AEZs) of Bangladesh. The soil sampling sites are shown in Fig.1 representing the Map of the country.

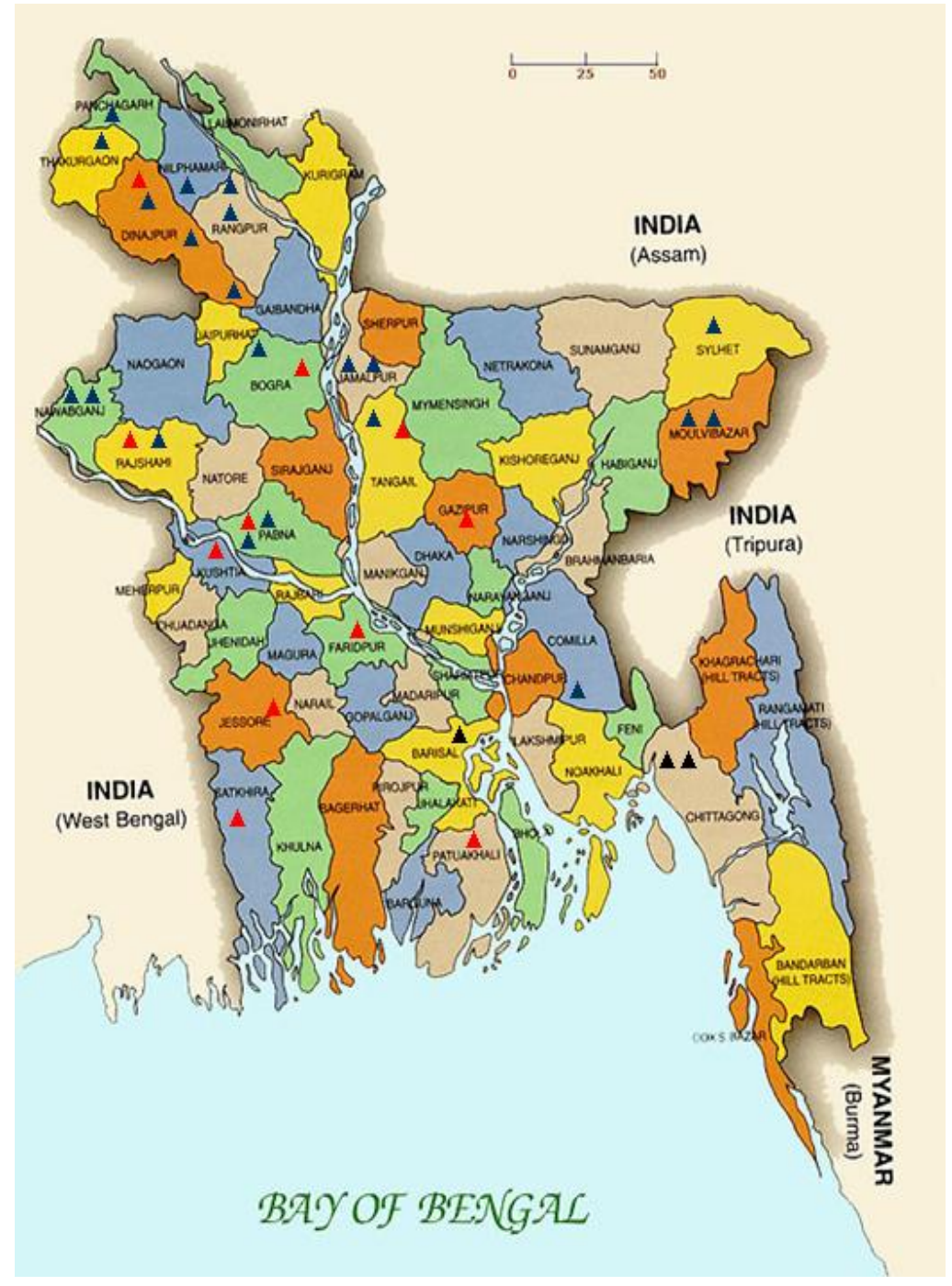

Fig. 1 Map showing the soil sampling sites representing major AEZ of Bangladesh $\Delta$ Indicates sampling sites. 


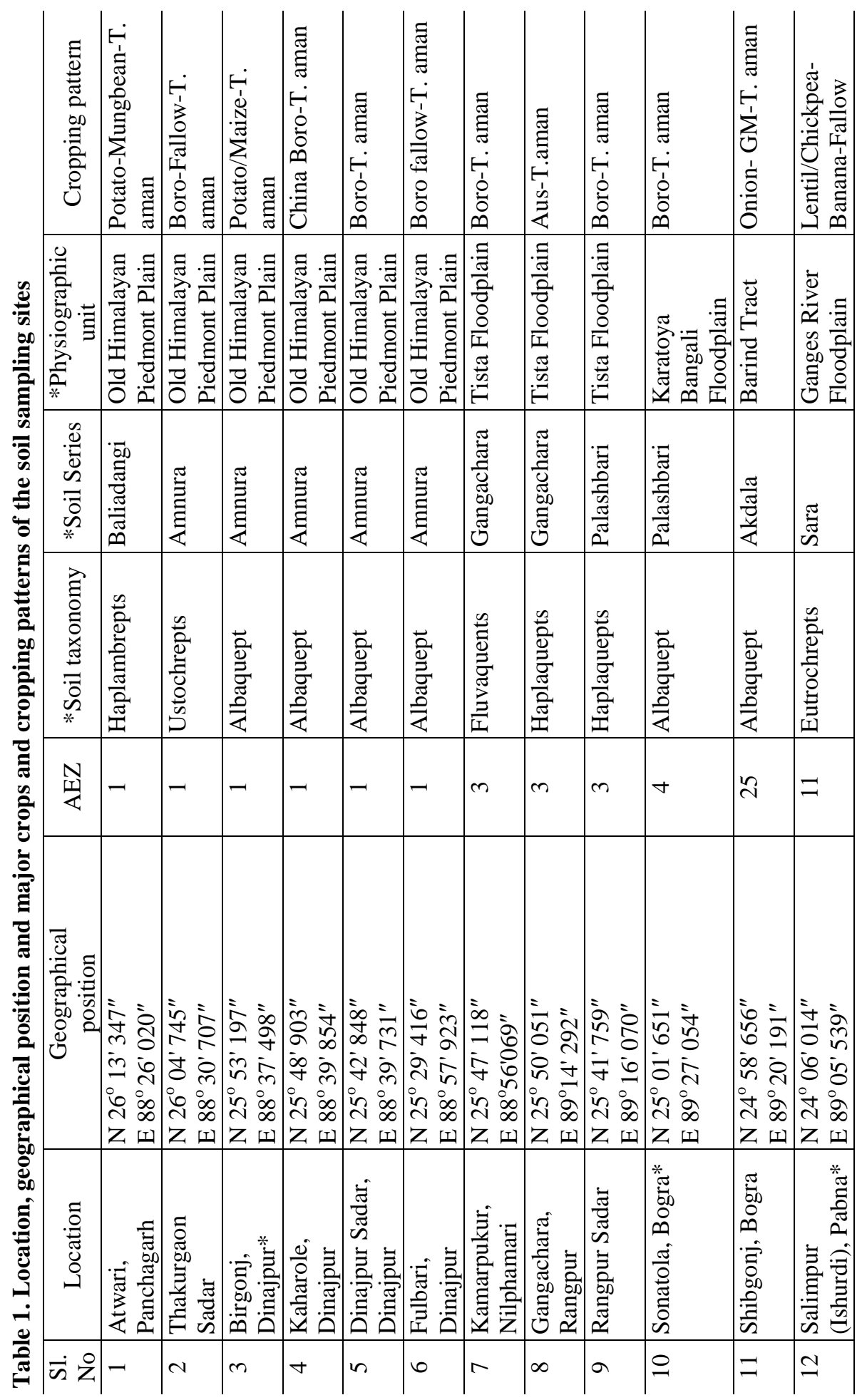




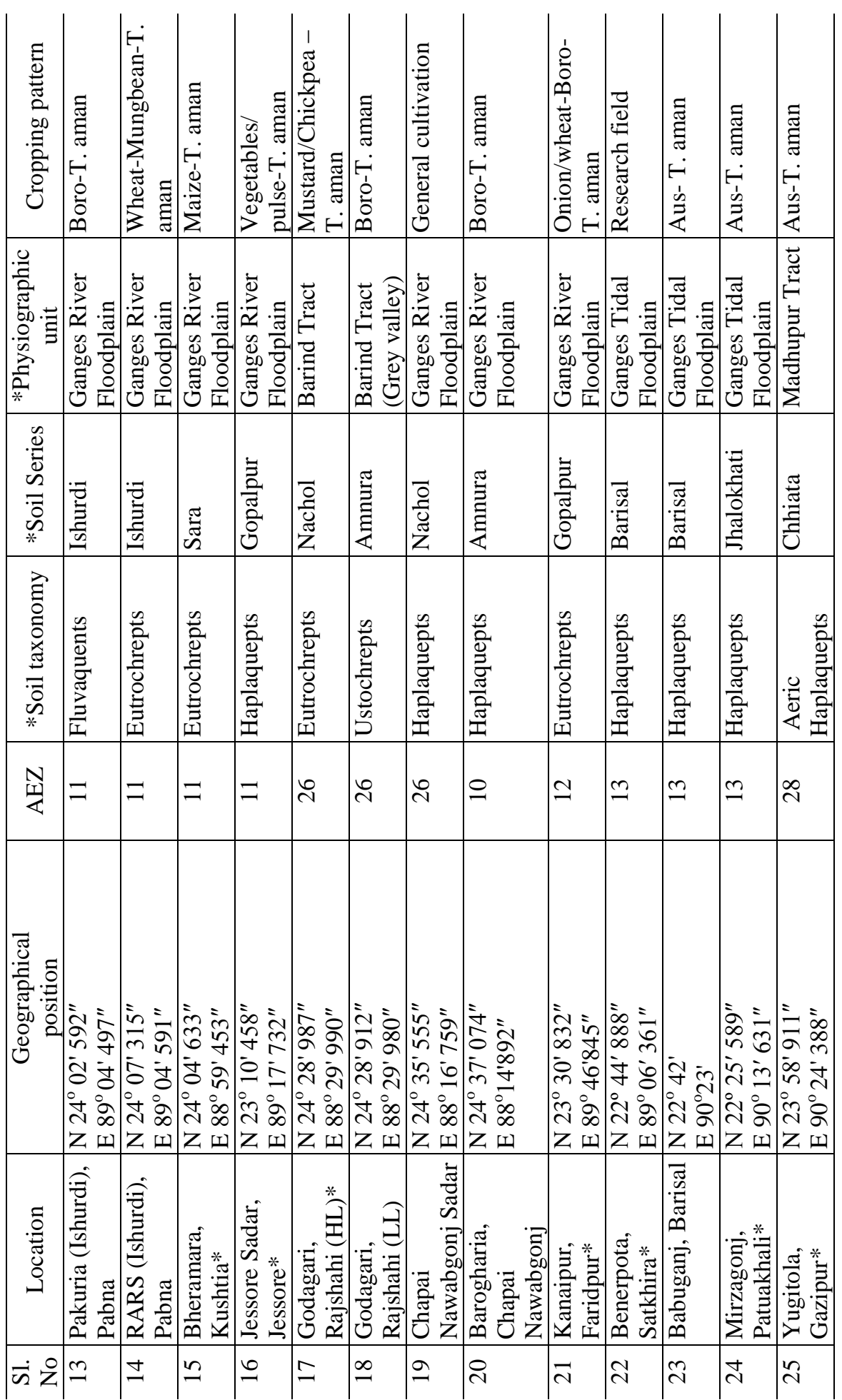




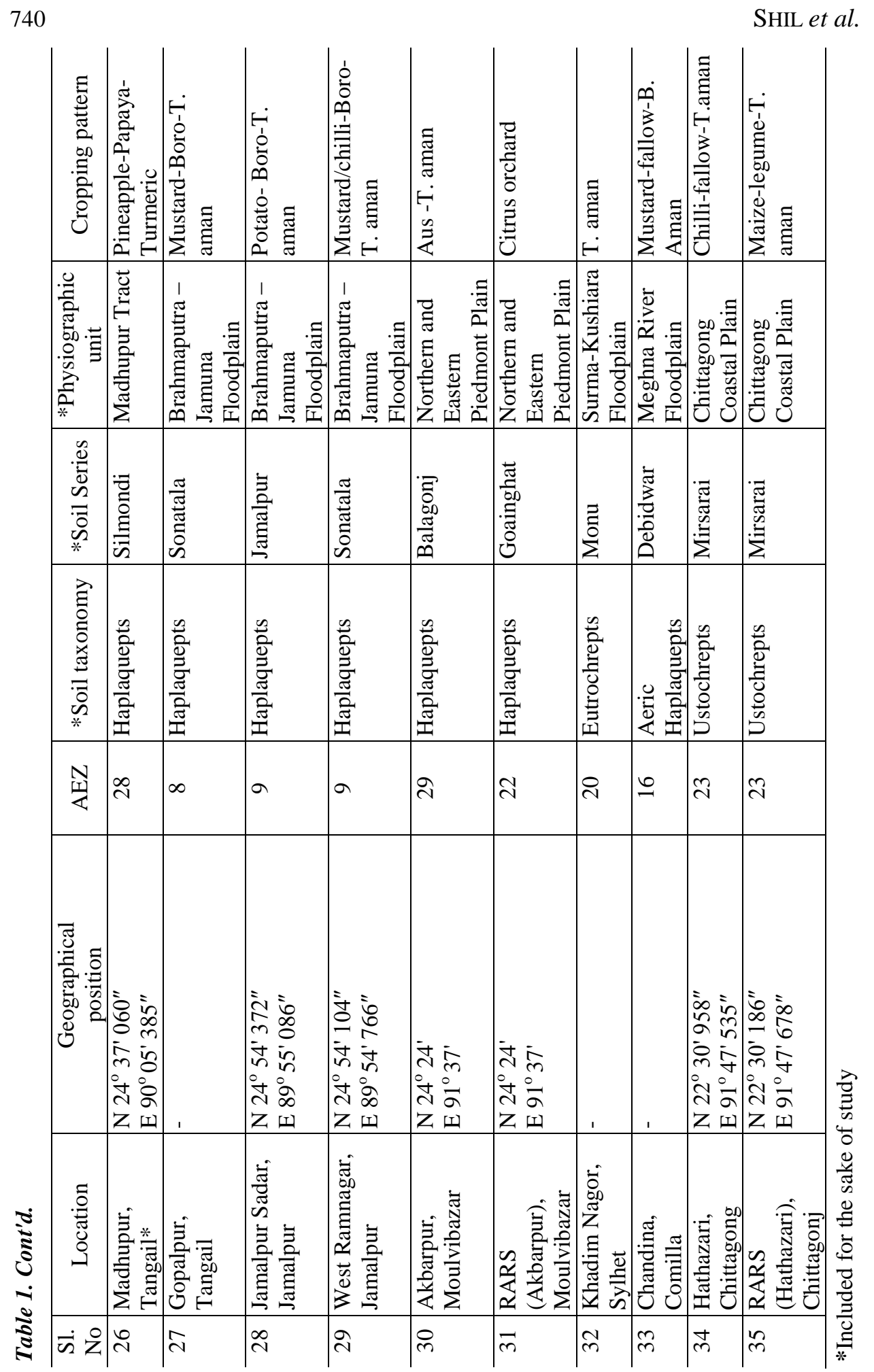


Soils: The collected soils represented 19 series, which covered 21 districts and 17 AEZs of Bangladesh. The location, geographical position, agro-ecological zones, soil taxonomy, soil series, physiographic units and major cropping patterns of the sampling sites are presented in Table 1.

Collection, preparation and analysis of soils: Five soil samples $(0-15 \mathrm{~cm})$ were collected from each of the selected sites and mixed together thoroughly to make a composite sample. Soils were mostly collected from farmers' field to get the representative sample of the locality during February - April 2009. Collected composite soil samples (35) were brought to the Soil Science Laboratory, BARI, Gazipur and air dried and ground to pass through 20 mesh sieve. The samples were then analyzed for texture, $\mathrm{pH}$, organic carbon, $\mathrm{CEC}$, exchangeable cations $(\mathrm{K}, \mathrm{Ca}, \mathrm{Mg}, \mathrm{Na}$ ), total $\mathrm{N}$, available $\mathrm{P}$ and available $\mathrm{S}$ following standard laboratory methods as stated below.

Analytical methods: Mechanical analysis of soils was done by hydrometer method (Bouyoucos, 1962) and the textural class was determined from Marshall's triangular co-ordinate following USDA system. A glass electrode $\mathrm{pH}$ meter calibrated with buffer $\mathrm{pH} 7.0$ and 4.0 measured the $\mathrm{pH}$ of the soil suspension maintaining soil: water ratio of 1:2.5 (Page et al., 1982). The $\mathrm{pH}_{\mathrm{KCl}}$ was determined by stirring $10 \mathrm{~g}$ soil in $25 \mathrm{ml}$ of $1.0 \mathrm{M} \mathrm{KCl}$ solution in a similar manner of $\mathrm{pH}_{\mathrm{H} 2 \mathrm{O}}$ determination. The difference between the $\mathrm{pH}$ in $\mathrm{KCl}$ and that in water gave the value of $\Delta \mathrm{pH}$.

$$
\Delta \mathrm{pH}=\mathrm{pH}_{\mathrm{KCl}}-\mathrm{pH}_{\mathrm{H} 2 \mathrm{O}}
$$

The value of the $\Delta \mathrm{pH}$ indicates the surface charge characteristics. A positive value of $\Delta \mathrm{pH}$ symbolizes positive surface charge while the negative value denotes negative surface charge. Cation exchange capacity of the soil was determined by Schollenberger (1980) method. Organic carbon was determined by wet oxidation method as described by Walkley and Black (1935) and the organic matter content was estimated by multiplying the percent organic carbon with the Van Bemmelen factor 1.73. Total $\mathrm{N}$ content of soil was determined following micro Kjeldhal method (Bremmer and Mulvancy, 1982). For the determination of available P, Bray 1 method (Bray and Kurtz, 1945) was used for acid soils while Olsen method (Olsen, 1982) was followed for neutral and alkaline soils. The filtrate was analyzed for P following Murphy and Riley (1962) method. Available $\mathrm{S}$ was determined by extracting the soil sample with $0.15 \% \mathrm{CaCl}_{2}$ solution as described by Page et al. (1982). The reading was taken using UV visible Spectrophotometer (Varian Model 50 Conc.) at $720 \mathrm{~nm}$ and $420 \mathrm{~nm}$ wavelength for $\mathrm{P}$ and $\mathrm{S}$, respectively. Exchangeable bases (K, $\mathrm{Ca}, \mathrm{Mg}$ and $\mathrm{Na}$ ) were extracted with $1 \mathrm{M} \mathrm{NH}_{4} \mathrm{OAc}$ solution $(\mathrm{pH}=7)$ (Thomas, 1982). In case of exchangeable $\mathrm{K}$, the reading was taken directly using AAS (Chemito AA 203) at $766.5 \mathrm{~nm}$ wavelength. For $\mathrm{Ca}, 2 \mathrm{ml}$ aliquot was diluted with $1 \mathrm{ml}$ of $\mathrm{La}_{2} \mathrm{O}_{3}$ and 7 $\mathrm{ml}$ of distilled water and then reading was taken using AAS (Chemito AA 203). In case $\mathrm{Mg}$ and $\mathrm{Na}, 1 \mathrm{ml}$ aliquot was diluted with $9 \mathrm{ml}$ of distilled water and reading was taken using the same AAS. 
Statistical analysis: The data were statistically analyzed for mean, range, standard deviation, standard error following the methods of descriptive statistics. Regression analysis was also done to observe the relationship between desired soil properties.

\section{Results and Discussion}

The experimental soils varied widely in texture, $\mathrm{pH}$, organic matter and essential plant nutrients like nitrogen, phosphorus, potassium, and sulfur content (Tables 2 and 3). Moreover, cation exchange capacity (CEC) and basic cation contents also varied greatly (Table 4).

\section{Soil particles and textural class}

Sand particle (2.00-0.05 mm) of the collected soils varied from 22-72\% (Table 2) where the highest sand content was recorded in Balagonj Sandy Loam (Soil No. 30) at Akbarpur, Moulvibazar under AEZ 22. The lowest sand content (22\%) was found in Sonatola Clay Loam (Soil No. 29) at West Ramnagar, Jamalpur under AEZ 9. In general, AEZ 1, 3, 22, 23 and 29 showed higher sand particles and AEZ 10,11, 12 and 13 contains lower sand particles. The rest of the AEZs under this study contain moderate level of sand (30-49\%).

The second category soil particle, silt $(0.05-0.002 \mathrm{~mm})$ also varied widely (16$50 \%$ ) among the studied soils (Table 2). The highest silt content (50\%) was obtained from Amnura Silt Loam (Soil No. 20) at Barogharia, Chapai Nowabgonj under AEZ 10. The higher (35-40\%) silt content was found in Soil No. 6, 14, 15, 19, 23, 28 and 33 across different AEZs as presented in Table 2. The moderate (30-34\%) amount of silt content was recorded in Soil No. 2, 8, 9, $13,16,24$ and 28 while rest of the soils contained low amount $(<30 \%)$ of silt particle. Thus silt content varied among the collected soils irrespective of AEZs.

The clay $(<0.002 \mathrm{~mm}$ ) content of the tested soils varied from 12 to $64 \%$ (Table 2) where the highest result was found in Barisal Clay (Soil No. 22) at Benerpota, Satkhira sunder AEZ 13. Soils collected from Bogra, Pabna, Jessore, Tangail and Gazipur had medium amount (30-34\%) of clay. The lower amount of clay (1729\%) was recorded from the soils of Rangpur, Dinajpur and Chittagong (AEZ 23). The lowest clay (12\%) content was found in Balagonj Sandy Loam (Soil No. 30) at Akbarpur, Moulvibazar under AEZ 29.

Thus textural class of soils collected from Faridpur (AEZ 12), Satkhira and Patuakhali (AEZ 13) was clay (Table 2). Clay loam soil was found in Barind, Rajshahi (AEZ 26), Jamalpur (AEZ 9) Tangai (AEZ 8 and 28), Bogra (AEZ 4 and 25) and Barisal (AEZ 13). The soils sampled from AEZ 11 (Pabna, Kushtia and Jessore) were mostly clay loam and loam. The collected soils of greater Dinajpur (AEZ 1) appeared to be either loam or sandy clay loam. The soils collected from Moulvibazar (AEZ 22, 29) and Chittagong (AEZ 23) were sandy textured (Table 2). 


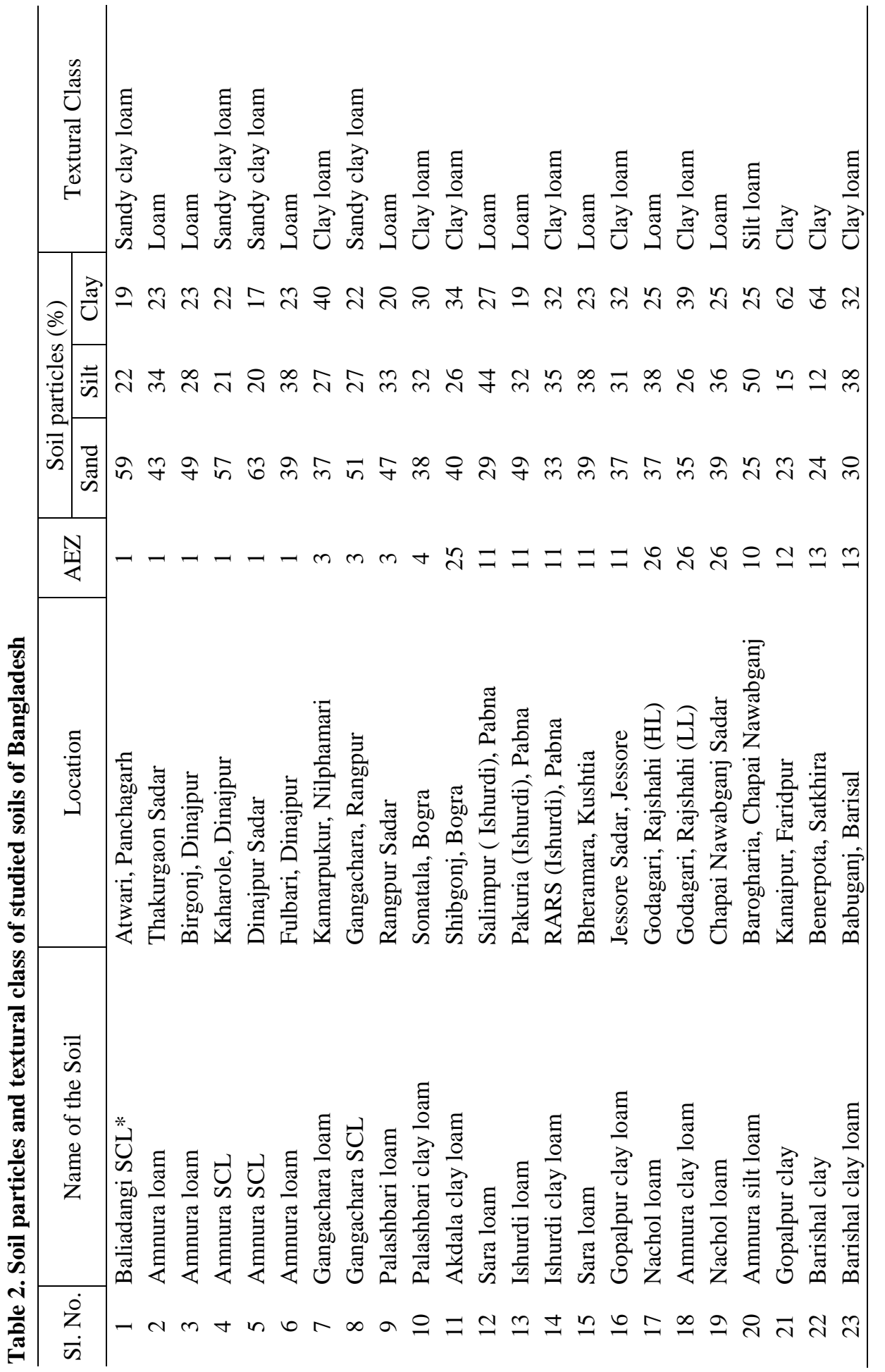




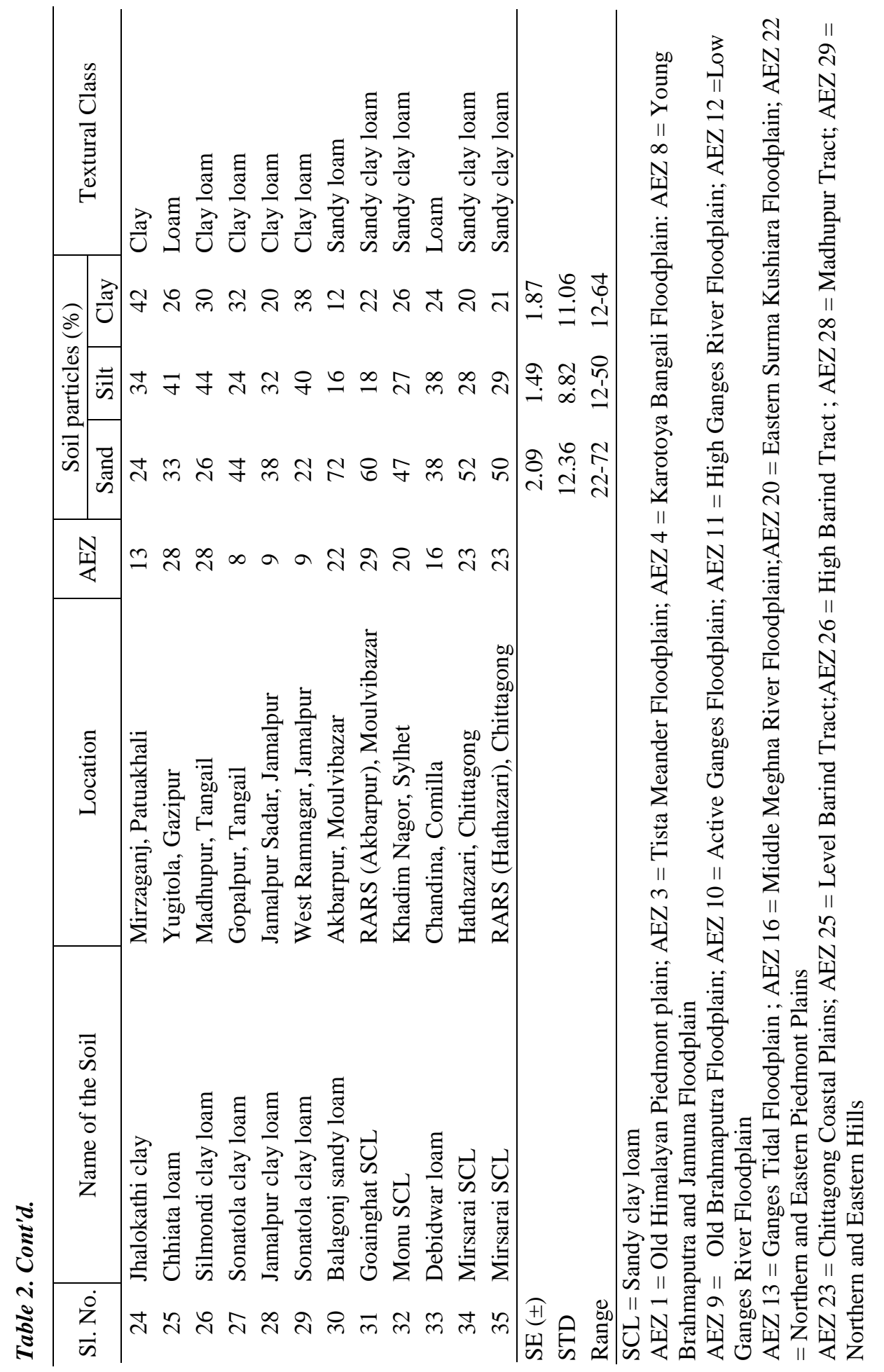




\section{Soil pH and charge characteristics}

Soil $\mathrm{pH}_{\mathrm{H} 2 \mathrm{O}}$ was moderately alkaline (8.0-8.3) in AEZ 11 except Gopalpur clay loam at Jessore $(\mathrm{pH} 7.5)$ where the highest value was observed in Sara loam and Ishurdi clay loam at Pabna and lowest in Sara loam at Bheramara, Kushtia (Soil No. 15). Strongly acid soil (pH 4.7-5.5) was found in AEZs 1, 3, 20, 22, 23, 28 and 29 where the highest result was found both in Gangachara Sandy Clay Loam at Ranpur (Soil No. 8) under AEZ 3, Balagonj Sandy Loam at Moulvibazar (Soil No. 30) under AEZ 22 and the lowest in Goainghat Sandy Clay Loam at Akbarpur (Soil No. 31) under AEZ 29. The tested soils of greater Dinajpur (AEZ 1), Barind region of Rajshahi (AEZ 26), Gazipur (AEZ 28), Madhupur of Tangail (AEZ 28) and Chittagong (AEZ 23) appeared to be strongly acidic in nature (Table 3). The results revealed that $65.7 \%$ of the tested soil was acidic while $25.7 \%$ was alkaline in nature.

Soil $\mathrm{pH}_{\mathrm{KCl}}$ showed slightly lower value in all the cases, however, the magnitude of difference between $\mathrm{pH}_{\mathrm{H} 2 \mathrm{O}}$ and $\mathrm{pH}_{\mathrm{KCl}}$ varied from 0.6 to 1.8 unit (Table 3) where the highest negative value was observed in Gopalpur Clay Loam Soil at Jessore (Soil No. 16) and the lowest value in Silmondi Clay Loam at Madhupur, Tangail (Soil No. 26) indicating the strength of negative charge characteristics of the tested soils. Since all the tested soils had lower $\mathrm{pH}_{\mathrm{KCl}}$ compared to $\mathrm{pH}_{\mathrm{H} 2 \mathrm{O}}$, essentially, all of them possess negative charge on the surface of the soil particles.

\section{Organic matter}

The tested soils varied widely in organic matter content (Table 3). About 68.6\% of the collected soils contained low (1.10-1.70\%) level of organic matter, $25.7 \%$ soils retained it at medium level (1.71-3.40) and 5.7\% soils showed it at very low $(<1.0 \%)$ level. The highest organic matter content $(2.40 \%)$ was found in Monu Sandy Clay Loam (Soil No. 32) at Khadim Nagor, Sylhet under AEZ 20 followed by Goainghut Sandy Clay Loam (Soil No. 31) at Akbarpur Moulvibazar under AEZ 29 and Barisal Clay at Benerpota, Shatkhira (Soil No. 22) under AEZ 13 and may be interpreted to be medium in status. The lowest organic matter $(0.88 \%)$ was observed in Barisal Clay Loam (Soil No. 23) at Babuganj, Barisal under AEZ 13, which was closest to the Debidwar Loam (Soil No. 33) at Chandina, Comilla under AEZ 16 and can be regarded as very low in category. Islam (2008) mentioned that organic matter content in Bangladesh soils is generally around $1 \%$ in most and around $2 \%$ in few soils. But a productive mineral soil should have at least $2.5 \%$ organic matter (Rijpma and Jahiruddin, 2004). Ali et al. (1997) reported that organic matter content in soils gradually depleted by 5-36\% during the period of 1967-1995. 


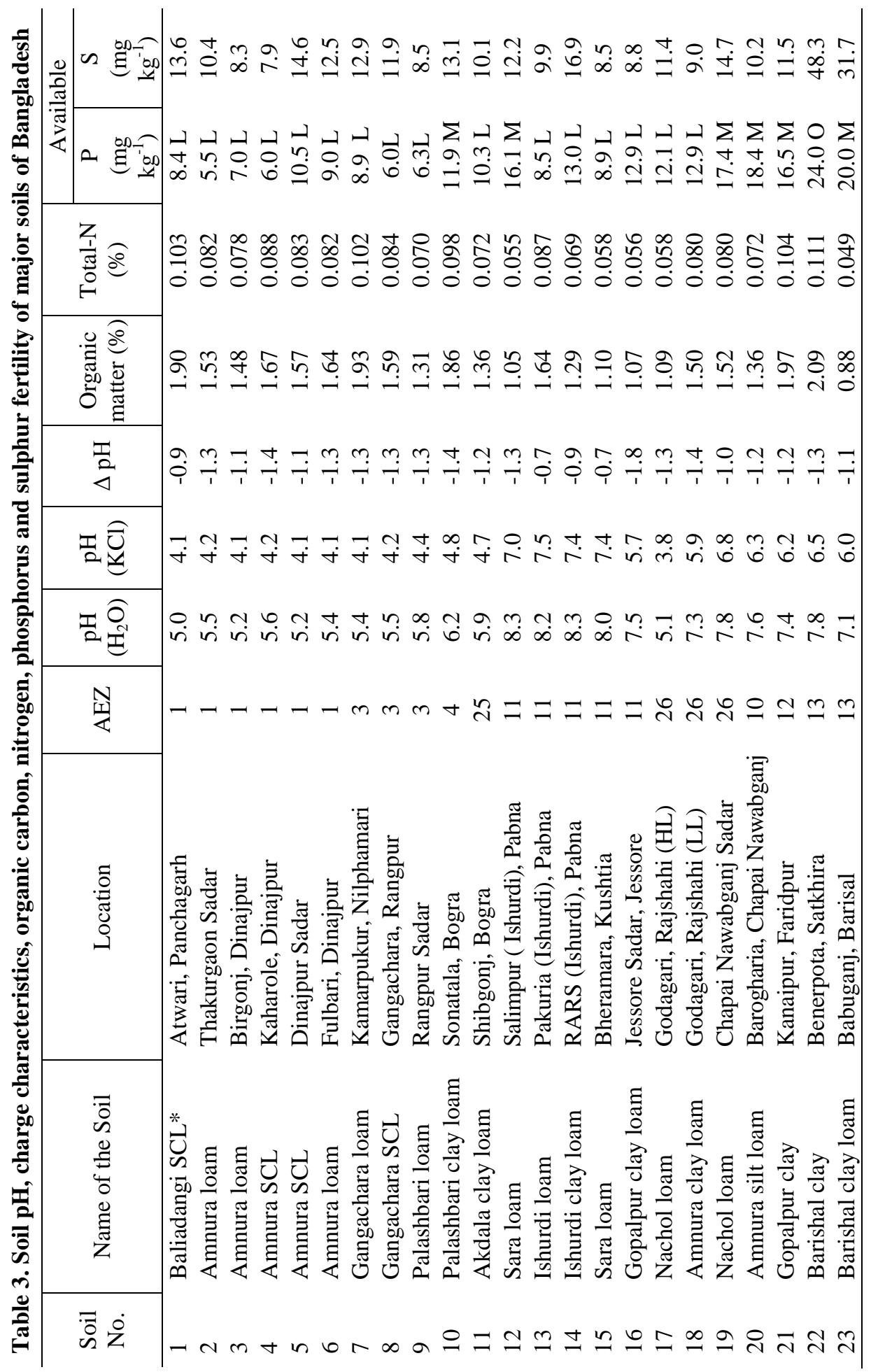




\begin{tabular}{|c|c|c|c|}
\hline$\sim \underset{60}{600}$ & 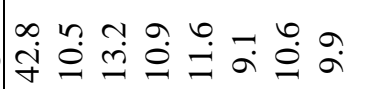 & 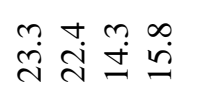 & \\
\hline 2 点 & 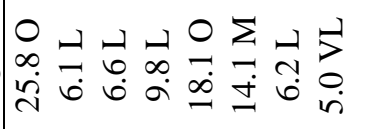 & 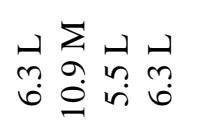 & \\
\hline$\frac{z_{1}}{0} \underset{0}{0}$ & 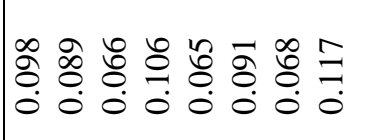 & 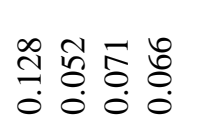 & 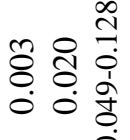 \\
\hline 营 & 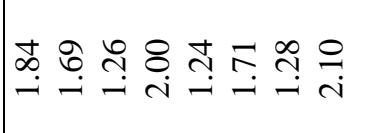 & 导哭守吉 & $\begin{array}{ll}\overrightarrow{8} & \overrightarrow{0} \\
0 & 0 \\
0 & 0\end{array}$ \\
\hline$\stackrel{\pi}{2}$ & 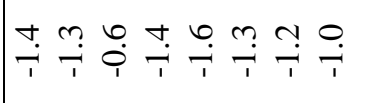 & $\underset{1}{T}$ & $\begin{array}{l}q \\
\stackrel{\tilde{T}}{0} \\
0\end{array}$ \\
\hline$\vec{v} \bar{v}$ & 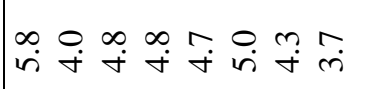 & 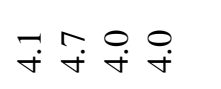 & \\
\hline 造过 & 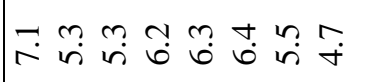 & $\ddot{n} \ddot{n} \ddot{n}$ & \\
\hline N & 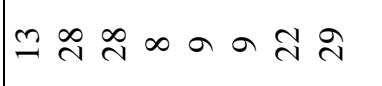 & $\stackrel{\sim}{\approx} \approx$ & \\
\hline 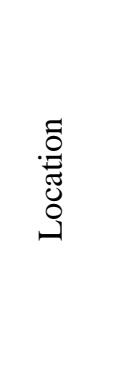 & 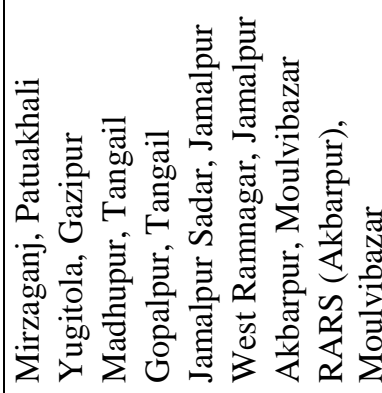 & 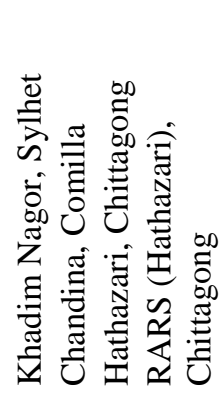 & \\
\hline 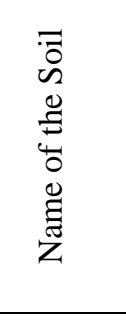 & 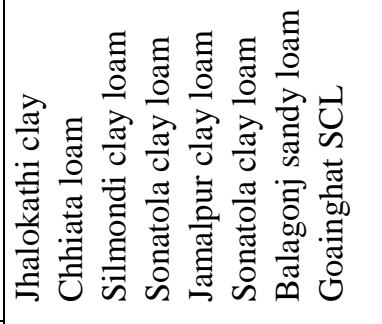 & 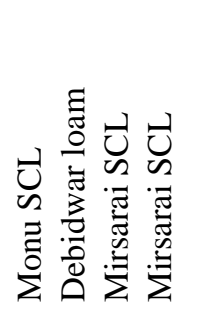 & \\
\hline$\overline{0} \dot{0}$ & 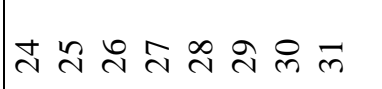 & $\stackrel{m}{n}$ & 茲 \\
\hline
\end{tabular}




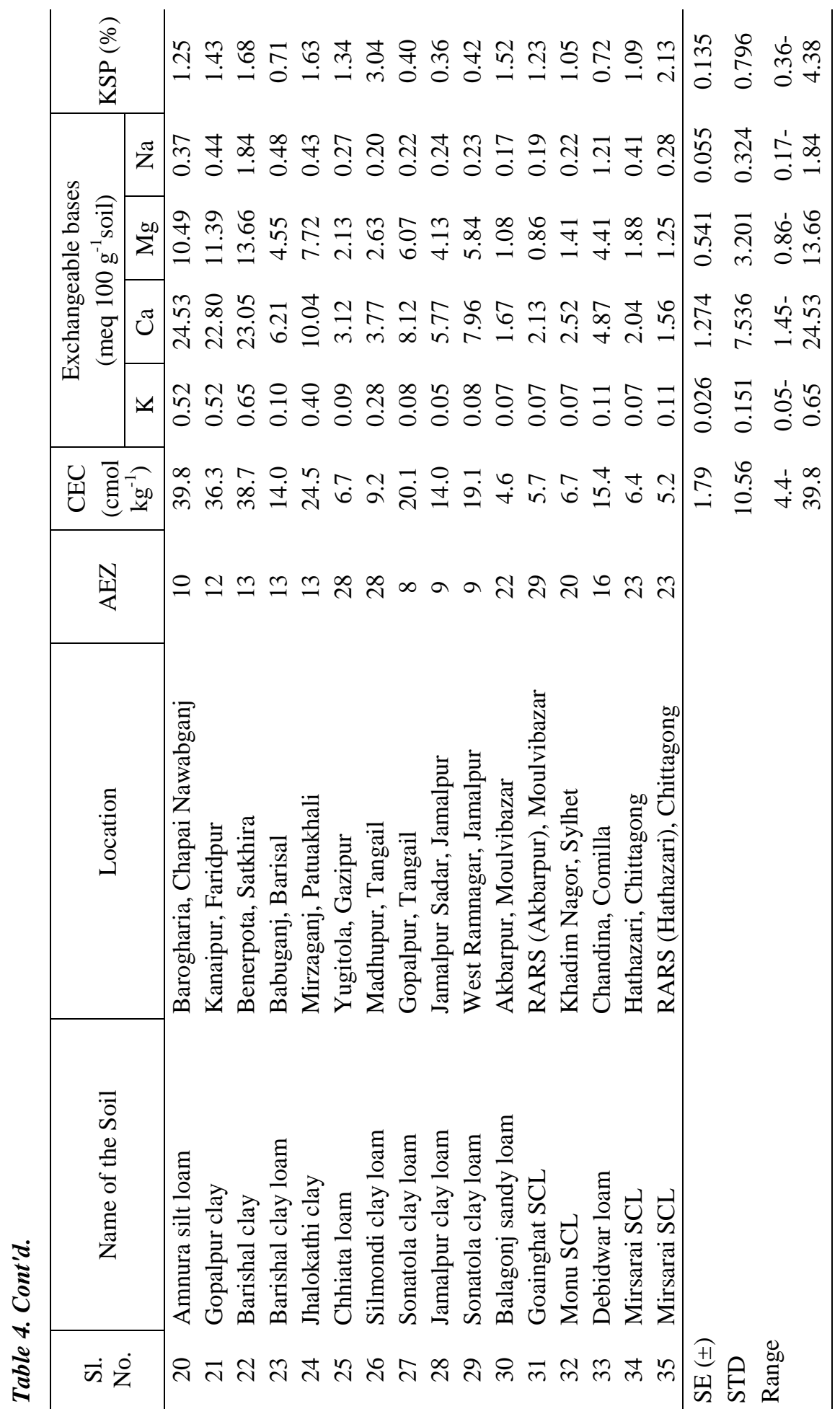




\section{Nitrogen}

Total-N content in soils varied greatly among different AEZs although almost all the tested soils appeared to be deficient $(<0.12 \%)$ in nitrogen content (Table 3 ). Like organic matter, the highest total $\mathrm{N}(0.128 \%)$ was recorded from Monu Sandy Clay Loam (Soil No. 32) at Khadim Nagor, Sylhet under AEZ 20. The lowest total N $(0.049 \%)$ was recorded from Barisal Clay Loam (Soil No. 23 ) at Babuganj, Barisal under AEZ 13, which was followed by Debidwar Loam (Soil No. 33) at Chandina, Comilla under AEZ 16 and Sara Loam (Soil No. 22) at Ishurdi, Pabna under AEZ 11. As such soil total $-\mathrm{N}$ status may not be categorized as higher or lower on the basis of AEZs but it was found higher where organic matter content was also higher. Portch and Islam (1984) studied 63 soil samples from different regions of Bangladesh and found that $100 \%$ of them were deficient in N. Moslehuddin (1993) also found $\mathrm{N}$ deficiency in Old Brahmaputra floodplain soil.

\section{Available phosphorus}

The available $\mathrm{P}$ content also varied among the tested soils to a great margin (Table 3). The highest available $\mathrm{P}\left(25.8 \mathrm{mg} \mathrm{kg}^{-1}\right)$ was found in Jhalokathi Clay (Soil No.24) at Mirzagonj, Patuakhali under AEZ 13, which was closely followed (24.0 mg kg-1) by Barisal Clay (Soil No. 22) at Benerpota, Satkhira under the same AEZ. The lowest available $\mathrm{P}\left(5 \mathrm{mg} \mathrm{kg}^{-1}\right)$ was obtained from strongly acidic soil of Moulavibazar (AEZ 29). Soils of Faridpur, Jamalpur, Jessore, Pabna, Chapainawabgonj, Rajshahi, and Barisal showed optimum amount available P. The rest of the studied soils were deficient in available P content. It was appeared that, $68.6 \%$ of the studied soils had the low level of available P, $22.9 \%$ showed medium level while $8.6 \%$ soils retained it an optimum amount. The fixation of $\mathrm{P}$ in acid soils might be the major reason for low available P. Moslehuddin et al. (1997) reported deficiency of available $P$ in calcareous soils of Ganges floodplain and acidic soils of terrace and hill areas. Portch and Islam (1984) found that $41 \%$ of soils contained $\mathrm{P}$ below the critical level while $35 \%$ were below the optimum level.

\section{Available Sulphur}

The tested soils varied greatly in respect of available $\mathrm{S}$ across different AEZs (Table 3). The highest available $S$ (48.3 mg kg $\mathrm{mg}^{-1}$ was recorded in Barisal Clay (Soil No. 22) at Benerpota Satkhira soil, which was almost similar (42.8 $\mathrm{mg} \mathrm{kg}^{-1}$ ) to that of Jhalakathi Clay at Mirzagonj, Patuakhali. It revealed that coastal regions soils hold higher amount of available $\mathrm{S}$. The optimum $\left(31.7 \mathrm{mg} \mathrm{kg}^{-1}\right)$ level of S was observed in Barisal Clay Loam Soil (Soil No. 23) at Babuganj, Barisal under AEZ 13, which was followed $\left(23.3 \mathrm{mg} \mathrm{kg}^{-1}\right)$ by Monu Sandy Clay Loam (Soil No 32) at KhadimNagor, Sylhet under AEZ 20. However, about 80\% 
soils contained low level of available $\mathrm{S}$ (7.9-14.7 $\mathrm{mg} \mathrm{kg}^{-1}$ ). Clay textured organic matter rich soils contained relatively higher amount of available $S$ than sandy textured one. Portch and Islam (1984) found that $68 \%$ of the studied soils were below the critical level for S. Bhuiyan (1991) reported that about 4 million ha of land was potentially deficient in S.

\section{Cation exchange capacity (CEC)}

The CEC of the tested soils varied from $4.4-39.8 \mathrm{cmol} \mathrm{kg}^{-1}$ (Table 4). The highest CEC (39.8 $\mathrm{cmol} \mathrm{kg}^{-1}$ ) was recorded in Amnura Silt Loam (Soil No.20) at Barogharia, Chapai Nowabgonj under AEZ 10, which was followed $(38.7 \mathrm{cmol}$ $\mathrm{kg}^{-1}$ ) by Barisal Clay (Soil No. 22) at Benerpota, Shatkhira under AEZ 13 and Gopalpur Clay (Soil No. 21) under AEZ 12. Moderate CEC (10-19 $\mathrm{cmol} \mathrm{kg}^{-1}$ ) was observed in AEZ 3 (Kamarpukur, Nilphamari), AEZ 4 (Sonatola, Bogra), AEZ 9 (Jamalpur Sadar), AEZ 13 (Babuganj, Barisal), AEZ 16 (Chandina, Comilla) and high land of Nachol Loam at Godagari, Rajshahi under AEZ 26. The low CEC (4.6-9.2 $\mathrm{cmol} \mathrm{kg}^{-1}$ ) was found in AEZ 22, 29 (Akbarpur, Moulvibazar), AEZ 20 (Khadim Nagor, Sylhet), AEZ 23 (Hathazari, Chittagong), AEZ 28 (Tangail, Gazipur), AEZ 3 (Rangpur) and AEZ 1 (Dinajpur and Panchagarh). Higher clay and organic matter content might have resulted in higher CEC in soil. The soil low in clay, organic matter and exchangeable bases found to hold low CEC. Harpstead et al. (2001) also reported that very sandy soils are at the low CEC while very clayey soils may have higher CEC.

\section{Exchangeable bases}

Exchangeable bases ( $\mathrm{K}, \mathrm{Ca}, \mathrm{Mg}$ and $\mathrm{Na}$ ) showed a wide variation in soils (Table 4). The exchangeable $\mathrm{K}$ content of the collected soils varied from 0.054 to 0.653 meq $100 \mathrm{~g}^{-1}$ showing the highest value in Barisal Clay at Benerpota, Satkhira under AEZ 13 and the lowest in Amnura Loam at Birgonj, Dinajpur under AEZ 1. The soils of Dinajpur (AEZ 1), Rangpur (AEZ 3), Bogra (AEZ 4), Akbarpur (AEZ 29 and AEZ 22), Sylhet (AEZ 20), Jamalpur (AEZ 9), Tangail (AEZ 8) and Chittagong (AEZ 23) were very low $\left(<0.09\right.$ meq $\left.100 \mathrm{~g}^{-1}\right)$ in exchangeable $\mathrm{K}$. The high level of $\mathrm{K}\left(0.361-0.45 \mathrm{meq} 100 \mathrm{~g}^{-1}\right)$ was found in Jhalokathi Clay at Mirzagonj, Patuakhali (AEZ 13). The very high level of K (>0.451 meq $100 \mathrm{~g}^{-}$ ${ }^{1}$ ) was of course recorded in Gopalpur Clay at Kanaipur Faridpur (AEZ 12), Amnura Silt Loam at Barogharia, Chapai Nawabganj (AEZ 10) and Barishal Clay at Benerpota Satkhira (AEZ 13). Study revealed that $40 \%$ of the collected soils were very low, $31.4 \%$ were low, $8.6 \%$ each of medium and optimum, and $11.4 \%$ contained high level of exchangeable $\mathrm{K}$. The result indicated that about $72 \%$ soils fall in either very low or low category in respect of exchangeable $\mathrm{K}$ status, which might be a great concern in achieving yield sustainability and maintaining K fertility in Bangladesh agriculture. Islam et al. (1992) reported 
that about $50 \%$ of the cultivable areas of Bangladesh found to be low in exchangeable $\mathrm{K}, 30 \%$ areas medium and the rest $20 \%$ areas (mostly in southern saline areas) were high to very high level of exchangeable K.

The content of exchangeable $\mathrm{Ca}$ of the tested soils varied from 1.45 to $24.53 \mathrm{meq}$ $100 \mathrm{~g}^{-1}$ where the highest result was observed in Amnura Silt Loam at Barogharia Chapai Nowabgonj (AEZ 10), which was closely followed by Barisal Clay at Benerpota, Satkhira, Gopalpur Clay at Kanaipur, Faridpur, Sara Loam at Salimpur, Pabna and also Sara Loam at Bheramara, Kushtia. Exchangeable calcium content was also found very high in Gopalpur Clay Loam at Jessore, Jhalokathi Clay at Mirzagonj, Patuakhali, Sonatola Clay Loam at Ram Nagor, Jamalpur and Gopalpur Tangail (Table 4). The lower Ca content was found in greater Dinajpur (mostly Amnura Loam), Rangpur (Gangachara SCL and Polashbari Loam) and Hathazari (Mirersarai SCL), which were actually either, at par or very few were just below the critical level $\left(2.0\right.$ meq $\left.100 \mathrm{~g}^{-1}\right)$. The calcareous soils (AEZ 10,11, 12 and 13) obviously contained very high level of $\mathrm{Ca}$. But non calcareous soils also showed fairly good level of Ca content except sandy textured soils (AEZ 1, 3, 23 and 29). Therefore, most of the studied soils were rich in calcium content.

The exchangeable Mg content varied from 0.86 to 13.66 meq $100 \mathrm{~g}^{-1}$ (Table 4). The highest $\mathrm{Mg}$ was found in Barisal Clay at Benerpota, Satkhira, which was followed by Gopalpur Clay at Faridpur and Amnura Silt Loam at Barogharia, Chapai Nawabganj. The soils collected from Rajshahi, Pabna, Jessore, Patuakhali, Tangail and Jamalpur also showed high level of exchangeable Mg. But sandy textured soil of greater Dinajpur, Rangpur, Moulvibazar showed lower level of exchangeable Mg. Magnesium was found to be deficient in the coarsetextured soils of Old Himalayan piedmont plain, Brown hill soils, and Grey floodplain soils of the northern part of the country (Islam et al., 1992). The reason behind less prevalence of Ca deficiency in comparison to $\mathrm{Mg}$ may be that $\mathrm{Ca}$ is automatically added to the soil as a part of P-and S-fertilizers.

The exchangeable Na content also varied widely among the tested soils (Table 4). The highest $\mathrm{Na}$ content $\left(1.84 \mathrm{meq} 100 \mathrm{~g}^{-1}\right)$ was found in Barisal Clay at Benerpota, Satkhira and the lowest $\left(0.17 \mathrm{meq} 100 \mathrm{~g}^{-1}\right)$ in Balagonj Sandy Loam at Akbarpur, Moulvibazar under AEZ 22. The content of Na for rest of the soils was 0.2 to $0.5 \mathrm{meq} 100 \mathrm{~g}^{-1}$. As Satkhira region is salt affected, that might be the major region for higher Na content in Barisal Clay Soil at Benerpota.

Potassium saturation percentage (KSP) varied from 0.36 to $4.38 \%$ (Table 4). The critical lower limit of the basic cation saturation ration (BCSR) was assumed to be 2\% (McLean, 1977). In this concept, 30 soil samples out of 35 had KSP less than 2\%. Gangachara SCL at Gangachara, Rangpur showed the highest KSP (4.38\%), which was followed (3.04\%) by Silmondi Clay Loam at Madhupur, 
Tangail (AEZ 28). Baliadangi SCL at Atwari, Panchagarh, Gangachara Loam at Kamarpukur, Nilphamari (AEZ 3) and Mireasarai SCL at Hathazari, exerted 2.19, 2.00 and 2.13\% KSP, respectively. According to the McLean (1977), soils containing less than $2 \% \mathrm{~K}$ saturation, needs $\mathrm{K}$ application. However, Abedin et al. (1991) found no benefit of K application to wheat in calcareous soil following BCSR concept. Again, Kopittke and Menzies (2007) disregarded the BCSR concept of $\mathrm{K}$ application based on their extensive review.

\section{Functional Relationship}

A significant $(\mathrm{p}=0.05)$ positive linear relationship was observed between soil $\mathrm{pH}$ and available phosphorus (Fig. 2). The coefficient of determination of the regression equation was $\left(\mathrm{R}^{2}=0.4287^{*}\right)$, which implies that available $\mathrm{P}$ of the tested soils governed by soil $\mathrm{pH}$ by $42.9 \%$ cases and that was statistically significant. The relationship between organic matter and total nitrogen appeared to be highly significant $(\mathrm{p}<0.01$ ), which revealed that total $\mathrm{N}$ content in soils was mostly dependent on organic matter content. The higher $\mathrm{R}^{2}$ value $0.991 * *$ indicated that $99 \%$ variability in total- $\mathrm{N}$ content in soils could be explained by organic matter content (Fig. 3). The relationship between CEC and clay content of the studied soils appeared to be statistically significant $(p=0.05)$. The $R^{2}$ value of the regression equation was $0.44^{*}$, which implies that $44 \%$ variability for CEC could be attributed by clay content (Fig. 4). The relationship between exchangeable $\mathrm{Na}$ with clay was non-significant $\left(\mathrm{R}^{2}=0.341^{\mathrm{ns}}\right)$, while exchangeable K showed significant relationship $(\mathrm{p}=0.01)$ with clay content (Fig. 5). Estimate showed that $50.4 \%$ variability in exchangeable $\mathrm{K}$ may be governed by clay content of the soils. But clay content did not influence exchangeable $\mathrm{Ca}$ content in studied soils significantly $\left(\mathrm{R}^{2}=0.2914\right)$. In contrary, a significant $(\mathrm{p}<$ 0.01) positive linear relationship was observed between clay content and exchangeable Mg. Regression equation showed that $65.6 \%$ variability in exchangeable Mg may be governed by clay content in soils (Fig. 6). Cation exchange capacity (CEC) gave significant positive linear relationship with exchangeable $\mathrm{K}, \mathrm{Ca}$ and $\mathrm{Mg}$ but such relationship with $\mathrm{Na}$ was non-significant (Fig. 7 and 8). CEC may explain 62.2, 92.3 and $83.9 \%$ variability for exchangeable $\mathrm{K}, \mathrm{Ca}$ and $\mathrm{Mg}$ content in soils, respectively. Higher the CEC there is a greater possibility of the exchangeable base content in soils except $\mathrm{Na}$. The studied soils were mostly non-saline which might be the major reason for the poor relationship with Na. 


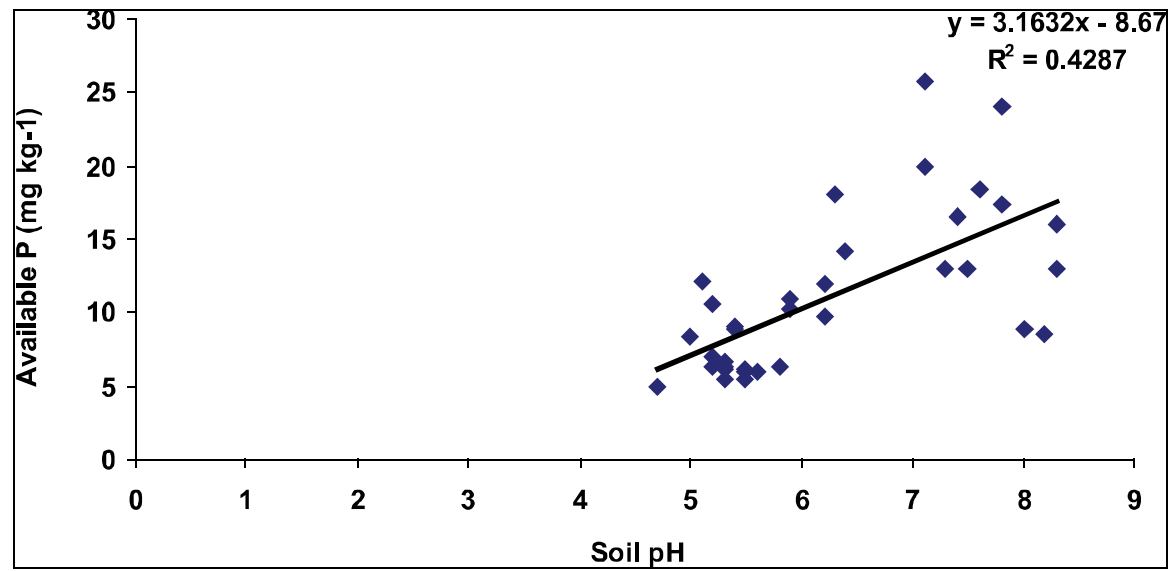

Fig. 2. Relationship between $\mathrm{pH}$ and available $P$ of the collected soil samples.

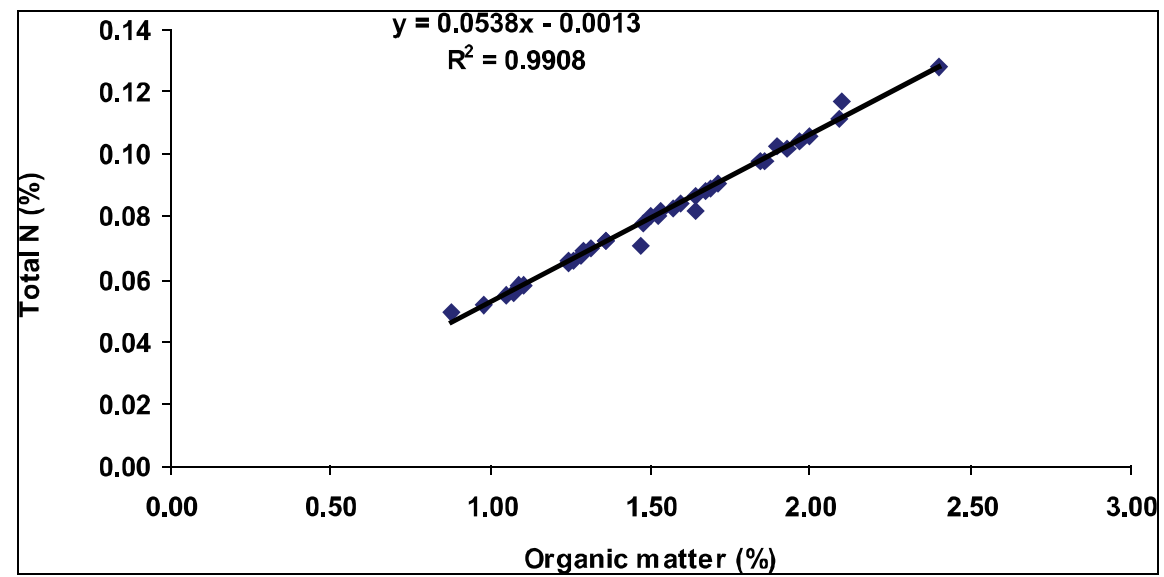

Fig. 3. Relationship between organic matter and total $\mathrm{N}$ content of the collected soils.

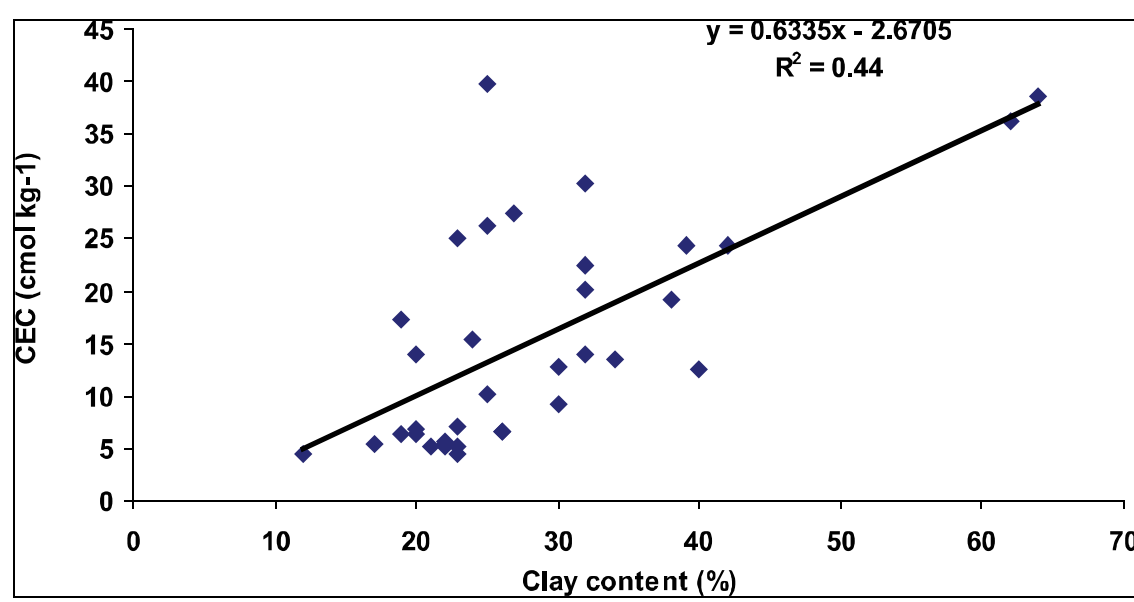

Fig. 4. Relationship between clay content and CEC of the collected soils. 


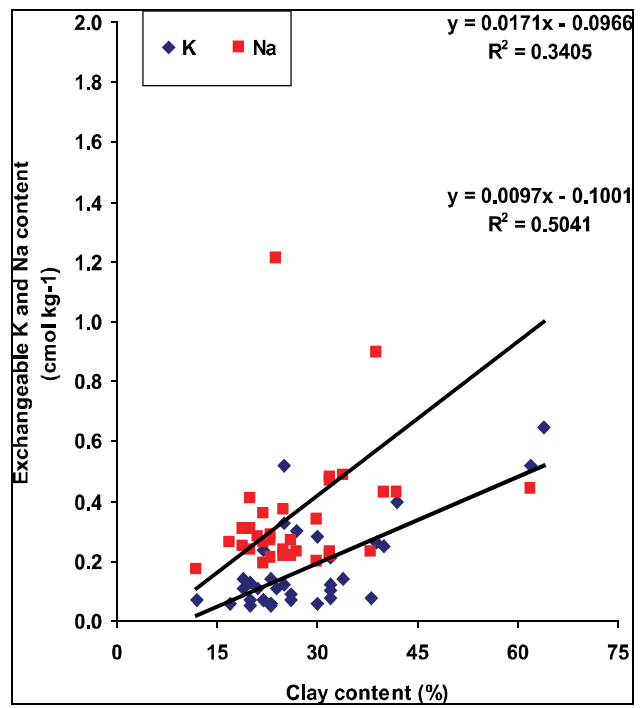

Fig. 5. Relationship between clay content with exchangeable $\mathrm{K}$ and $\mathrm{Na}$ of the collected soils.

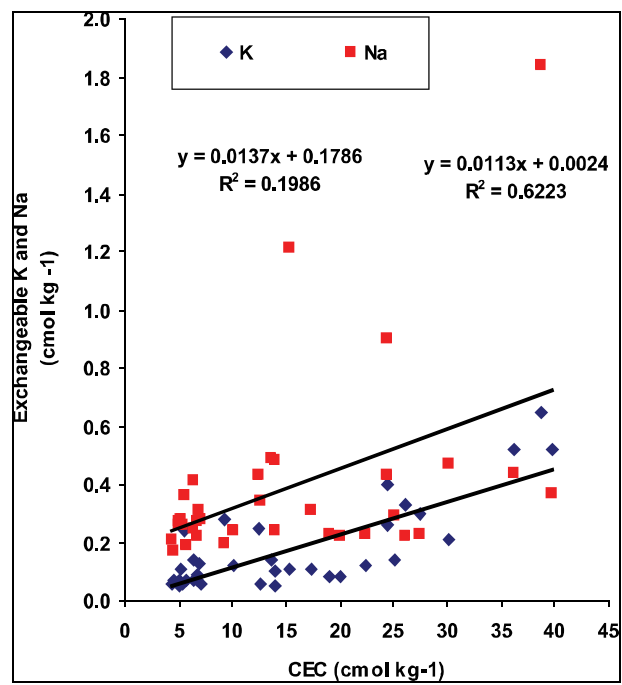

Fig. 7. Relationship between CEC with exchangeable $\mathrm{K}$ and $\mathrm{Na}$ of the collected soils.

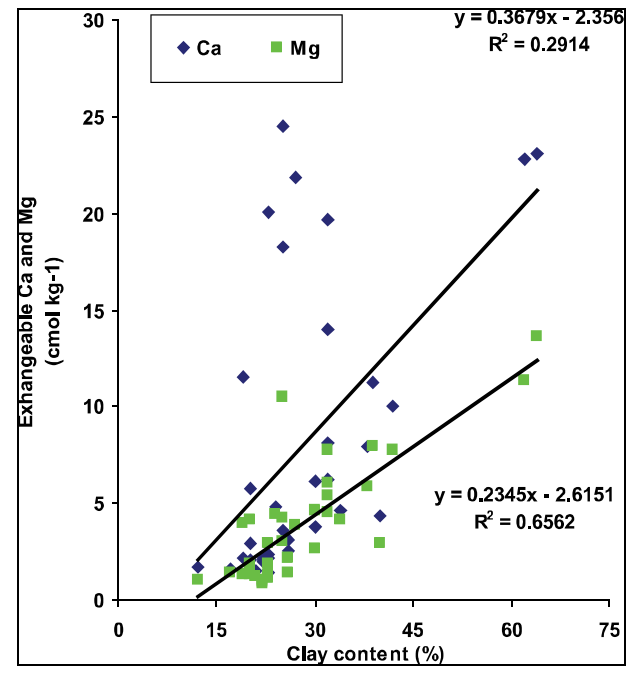

Fig. 6. Relationship between clay content with exchangeable $\mathrm{Ca}$ and $\mathrm{Mg}$ of the collected soils.

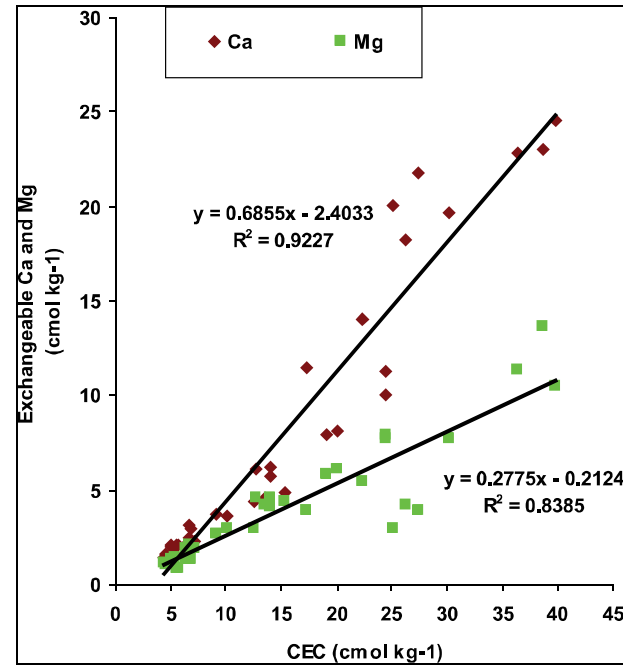

Fig. 8. Relationship between CEC with exchangeable $\mathrm{Ca}$ and $\mathrm{Mg}$ of the collected soils.

\section{Conclusion}

Studied soils varied widely in texture, $\mathrm{pH}, \mathrm{CEC}$, organic matter and essential plant nutrient elements. Sand dominated loamy textured soils were found in northern region while soils of north eastern and south eastern part except coastal 
belt was mostly sandy textured. The middle part of the country was dominated by clay loam soil. The soils of south-western coastal belt appeared to be clay textured. The majority of the tested soils found to be acidic in nature. Organic matter status appeared to be remarkably low. Nitrogen deficiency was found in all soils. Available P and S contents were mostly low. Exchangeable K content was low to very low except clay rich soils of Ganges floodplain and Ganges tidal floodplain regions. The calcareous soils contained very high level of $\mathrm{Ca}$. But non calcareous soils also retained fairly good level of exchangeable Ca except sandy textured ones. Magnesium deficiency was found in sandy textured soils but rest of the soils hold optimum to high level of exchangeable $\mathrm{Mg}$. Thus the fertility status of most of the Bangladesh soils (except AEZ 10, 12, 13 and to some extent 11) appeared to be low to very low, which demand judicious management in order to achieve food security and to maintain the soil fertility.

\section{References}

Abedin, M.J., Blume H.P, Bhuiyan Z.H. and Eaqub M. 1991. Water and nutrient dynamics of a paddy soil of Bangladesh. Z. Pflanzenern. Bodenk. 154: 93-99.

Ali M. M., Shaheed S. M. and Kubota D. 1997. Soil degradation during the period 1967-1995 in Bangladesh. II. Selected chemical characters. Soil Sci. Plant Nutr. 43: 879-890.

Bhuiyan, N. I. 1991 Appropriate nutrient ratios for soils and crops of Bangladesh. Paper presented in the conference on Production and Use of Multinutrient Fertilizer in Bangladesh, on 25-26 November, 1991 at Bangladesh Agricultural Research Council, Dhaka, Bangladesh

Bouyoucos, G.J. 1962. Hydrometer method improved for making particle size analysis of soils. Agronomy J. 54: 464-465.

Bray, R. H. and Kurtz, L. T. 1945. Determination of total, organic and available forms of phosphorus in soils. Soil Sci. 59: 39-45.

Bremner, J.M., and.Mulvaney C. S. 1982. Nitrogen-Total. In: Methods of Soil Analysis, Part 2, C.A, Black (ed-in-chief). Agronomy series No. 9. Am. Soc. Agron., Inc., Publ., Madison, W.I. Pp.595-624.

FAO-UNDP 1988 Land Resources Appraisal of Bangladesh for Agricultural Development: Agro-ecological Regions of Bangladesh. Technical Report No. 2, FAO, Rome.

FRG. 2012. Fertilizer recommendation guide-2012, Bangladesh Agricultural Research Council (BARC), Farmgate, Dhaka-1215. 49p.

Harpstead, M.I., Sauer T. J. Bennet W.F and Bratz M. C. 2001. Soil colloids and chemistry. In: Soil Science Simplified Fourth Edition. Iowa State University Press, USA. Pp. 64-67.

Islam, M. S. 2008. Soil fertility history, present status and future scenario in Bangladesh. Bangladesh J. Agric. and Environ. 4 (Special Issue): 129-151. 
Islam, M. S., Amin M. S. and Anwar M. N. 1992. Integrated soil fertility management in Bangladesh. In"Proceedings of the Inter-Congress Conference of Commission IV of ISSS on Improving Soil Management for Intensive Cropping in the Tropics and SubTropics", ed. by M. S. Hussain, S. M. I. Huq, M. A. Iqbal and T. H. Khan, Pp. 147-156

Khan, M. S., Shil, N. C. and Noor, S. 2008. Integrated nutrient management for sustainable yield of major vegetable crops in Bangladesh. Bangladesh J. Agric. and Environ. 4 (Special Issue): 81-94.

Kopittke, P.M. and Menzies N.W.. 2007. A review of the use of the basic cation saturation ratio and the "ideal" soil. Soil Sci. Soc. Am. J. 71: 259-265.

McLean, E.O. 1977. Contrasting concepts in soil test interpretation: Sufficiency levels of available nutrients versus basic cation saturation ratios. p. 39-54. In: T.R. Peck et al. (ed.) Soil testing: Correlating and interpreting the analytical results. Am. Soc. Agron Spec. Publ. 29. Madison, WI, USA.

Miah, M. A., Saha P. K. Islam, A, Hasan, M. N. and Nosov, V. 2008. Potassium fertilization in rice-rice and rice-wheat cropping system in Bangladesh. Bangladesh J. Agric. and Environ. 4 (Special Issue): 51-67.

Moslehuddin, A. Z. M. 1993 A Detailed survey of the fertility status oj'Bangladesh Agricultural University Farm Soils. M. SC. Thesis, Soil Science Department of Bangladesh Agricultural University, Mymensingh, Bangladesh

Moslehuddin, A.Z.M, Laizoo, S and Egashira, K. 1997. Fertility status of Bangladesh soils- A review. J. Fac. Agr., Kyushu Univ. 41 (3.4), 257-267.

Murphy, J. and Riley J. P. 1962. A modified single solution method for the determination of phosphate in natural waters. Analytica Chemica Acta. 27: 31-36.

Olsen, S.R. and Sommers L.E. 1982. Phosphorus. In methods of soil analysis, Part 2, A.L. Page, R.H. Miller, and D.R. Keeney (eds.) $2^{\text {nd }}$ ed. Agronomy series No.9, Amer. Soc. Agron. and Soil Sci. Soc. Am., Inc., Madison, W.I. Pp. 403-430.

Page, A.L., Miller R. H. and Keeney D. R. 1982. Methods of soil analysis, Part -2, Second edition. Am. Soc. Agron., Inc., Madison, Wisconsin.

Portch, S. and Islam M. S .1984. Nutrient status of some of the more important agricultural soils of Bangladesh. In "Proceedings of International Symposium on Soil Test Crop Response Studies", Bangladesh Agricultural Research Council and Soil Science Society of Bangladesh, Pp. 97-106

Rijpma, J, and Jahiruddin, M. 2004. National strategy and plan for use of soil nutrient balance in Bangladesh. Asia Pacific J, Environ. Dev. 1: 48-67.

Schollenberger, C.J. 1980.In: Analytical methods of nutrients in soil. Ed. Committee of the analytical methods of nutrients in soil, Japanese Soc. Soil Sci. and Plant Nutri., Yokendo Company, Tokyo. Pp. 34-41.

Walkley, A.C. and, Black T.A. 1965. Estimation of soil organic carbon by chromic acid titration method. Soil Sci. 47: 29-38. 